\title{
CONTROLLING THE GREEN PEACH APHID, MYZUS PERSICAE INFESTING PEACH TREES BY RELEASING THE SEVEN SPOTTED LADY BEETLE, COCCINELLA SEPTEMPUNCTATA L.
}

\author{
MANGOUD, A. A. H. \\ Plant Protection Research Institute, ARC, Dokki, Giza
}

(Manuscript received 21 January 2009)

\begin{abstract}
The seven-spotted ladybird, Coccinella septempunctata L. (Coleoptera : Coccinellidae), is an important predator of aphids: it plays an obvious role in reducing the population of the green peach aphid, Myzus persicae (Sulzer) (Homoptera : Aphididae) attacking peach trees. In the present study, C. septempunctata was released (one time), at early April 2006 and repeated in 2007, at Qalubiya Governorate at rates of 30,60 and 90 eggs/tree. During the first season (2006), the reduction percentages in the population of $M$. persicae increased gradually with elapse of time reaching the maximum. The achieved average reductions in aphid population were $77.50,82.33$ and $97.24 \%$ at the end of November for the three releasing levels, respectively in the first year (2006). However, the same trend was achieved in the second season (2007).

The present work, has shown that the seven-spotted ladybird, Coccinella septempunctata L. could used successfully, as a biocontrol agent among an integrated program for controlling the green peach aphid on the peach trees.
\end{abstract}

\section{INTRODUCTION}

The green peach aphid, Myzus persicae (Sulz.) (Homoptera : Aphididae) is a serious pest of many crops and fruit trees and also has bee considered as an insect pest of economic importance on young terminal apple leaves (Mangoud 2000). The insect species appears on leaves in a few numbers and infesting the terminal (new) leaves, while, not infesting mature leaves of fruit trees (Mangoud 1994\&2000). The aphid pest feed in colonies of large numbers on young new emerging leaves, mostly on the under-surface and on tender parts and cause considerable damage. They suck the cell sap from leaves, lowering its vitality, turn yellow and crinkled. In addition, honeydew excretions and transmission of virus diseases are important problems (Mangoud, 2000).

The seven-spotted ladybird, Coccinella septempunctata L. (Coleoptera : Coccinellidae) is the commonest ladybird beetle known in Egypt, it is an important predator of many aphid species; eggs and small nymphs of mealybugs, jassids, eggs and larvae of cotton leafworm (Ibrahim, 1948 \& 1955a and b). The adults and early stages 
are often encountered in large numbers on the plants infested with aphids. They feed on these harmful insects and often play a great role in suppressing them under control. The seven-spotted ladybug, Coccinella septempunctata L. lives in a wide variety of habitats. Any place where there are plants and aphids may attract this species (Fleming, 2000). Both the adult and larval stages feed on harmful insects, such as aphids and scale insects (Anonymous, 1997). Adults can be consuming up to 100 aphids per day (Arnett et al., 1980). The ladybug kills its prey outright and then devours it (Waldbauer, 1998).

The present work aimed to evaluate the management of the green peach aphid, Myzus persicae (Sulzer), (Homoptera: Aphididae) by releasing the seven spotted lady beetle, Coccinella septempunctata (Coleoptera : Coccinellidae) on peach trees at Qalubiya Governorate.

\section{MATERIALS AND METHODS}

\section{Mass rearing of the seven-spotted ladybird, Coccinella septempunctata} and its prey the cowpea aphid, Aphis craccivora (Koch):

\subsection{Mass rearing of A. craccivora as a prey:}

$A$. craccivora is considered the most preferable prey for mass production of $C$. septempunctata. Strong culture of this aphid should be available during the rearing time to maintain the predator rearing process.

The broad bean, Vicia faba seeds were planted in plastic trays (25X 40X15 $\mathrm{cm}$ ) or foam trays (60X25X20 cm with 109 wholes) contained peat muss. The seeds were planted at 1-2 cm deep and followed with irrigation and fertilizers as required. When the first leaflet appeared after about one week from cultivation, bean leaves were infested with $A$. craccivora which distributed over the new foliage of cultivated trays. Culturing of faba bean plants and artificial aphid infestation were continuous process carried out at weekly intervals.

The infested trays were followed until the population of $A$. craccivora increased and become suitable for using as prey to the ladybird, C. septempunctata.

A. craccivora colonies were cultured under laboratory conditions $\left(23 \pm 2^{\circ} \mathrm{C}\right.$ and $60 \pm 5 \%$ R.H.) on broad beans (Vicia faba). Such leaves of beans were infested by different stages of aphids and kept under a glass chimney which its upper opening was covered with white muslin. The potted plants were irrigated and fertilized whenever necessary and kept in wooden cages $(100 \times 135 \times 135 \mathrm{~cm})$ with nylon gauze sides using the method described by Mangoud (2003). Instars of $A$. craccivora were originally collected from infested broad beans, cultivated in Agriculture Research Center Farm. 


\subsection{Mass rearing of $C$. septempunctata:}

When the population of $A$. craccivora increased and reached to suitable density individuals (approximately 100 individuals/plant) on faba bean plants, these plants were inoculated with $C$. septempunctata. The stock culture of ladybird was obtained from infested plants and transferred to laboratory. Only 10 adult $\hat{\alpha}+10$ adult $q$ of ladybird (to prevent larval cannibalism) were transferred to rearing cages (30 cm diameter X $25 \mathrm{~cm}$ high) and kept in wooden cages (100X135X135 cm) with nylon gauze sides. To maintain the predator culture, a suitable number of the prey was daily offered to the predator.

\subsection{Egg picking:}

The method for egg laying [black polyethylene strips fixed inside a plastic cylindrical (10 cm length $\times 2 \mathrm{~cm}$ diameter) for laying eggs and put in the rearing pots]. After laid egg-masses, they were removed from plastic cylinders to separate the eggmasses from the cylindrical plastic and to be ready to stick on the carton paper card for releasing. The plastic cylinder was checked twice/day for egg-masses because of the cannibalistic habits of the adults, especially when there was a shortage of host food (its prey). In order to provide the developing larva with sufficient food throughout their developmental period, it was necessary to increase the amount of food with the advancement of their development.

\section{Release of C. septempunctata:}

Releasing was conducted on peach trees, at Qalubiya Governorate during 2006 and 2007 years. The selected trees for the present investigation were away from any pesticide contamination for five months. The trees were about 14 years old, with about 5-6 meters in height similar in size, age, shape, height and vegetation as possible and infested by M. persicae.

Three levels of $C$. septempunctata eggs; first level consists of 30 eggs (one card), second level consists of 60 eggs (two cards) and the third one consists of 90 eggs (three cards) were released to encouragement the normal predator population to reduce the aphid. C. septempunctata were released (one time), by the beginning of April 2006 and repeated in the same time in 2007. The peach trees were divided into 4 replicates, each replicate consists of 4 trees (16 trees) for each plot. Another 16 trees were selected to be as a check plot. $C$. septempunctata were released by hanging the carton cards including egg-mass near from the infestation (terminal shoots) of each tree, which consider as the best time for release (Mangoud 2003).

Samples were randomly taken monthly and counting started from the beginning April till the beginning November (Mangoud, 2003). 
Twenty new leaves were examined from the terminal shoots (terminal part of branch), twenty mature leaves (mid leaves) were examined from the mid part and other twenty mature leaves (base leaves) were examined from the base parts of the same branch. Examination of the leaves in the field was made by a hand lens for counting the alive nymphs, adult females and their predators. Both surfaces of the leaf were inspected for the presence of aphid (Mangoud, 2000).

\section{Statistical analysis:}

The percent reduction of aphid after $C$. septempunctata release was calculated according to Henderson and Tilton equation (1955).

\section{RESULTS AND DISCUSSION}

\section{First year (2006):}

Three levels of $C$. septempunctata eggs; first level (30 eggs on one card), second level (60 eggs on two cards) and the third level (90 eggs on three cards) were released (one time), by the beginning of April 2004.

\subsection{First level of release ( 30 eggs/tree):}

In first level of release, the pre-count of aphid was 48 individuals/leaf in the releasing area, while it was also 45 individuals/leaf in (check trees).

The results shown in Fig. (1) indicated that the number of M. persicae in the $1^{\text {st }}$ release plot decreased gradually from 48 in April to $43,39,31,21,15,14$ and 12 individuals/leaf in May, June, July, August, September, October and November, respectively as compared to check plot (aphid populations changed from 45 individuals/leaf in April to 55, 63, 75, 66, 59, 54 and 50 individuals/leaf in the same dates, respectively. In addition, the results show that the percent reduction of aphid species complex in $1^{\text {st }}$ release plot increased gradually to reach $26.70,41.96,61.25,70.17$, $76.17,76.69$ and $77.50 \%$ in May, June, July, August, September, October and November, respectively.

\subsection{Second level of release ( 60 eggs/tree):}

In the second level of release, the pre-count number of $M$. persicae in release area was 63 individuals/leaf, while it was 69 individuals/leaf in (check trees).

The results illustrated in Fig. (2) indicated that the number of $M$. persicae in the $2^{\text {nd }}$ release plot decreased gradually from 63 on April to $45,39,28,19,16,14$ and 10 individuals/leaf in May, June, July, August, September, October and November, respectively, while aphid populations changed from 69 individuals/leaf in April to 75, $89,101,95,86,81$ and 62 individuals/leaf in the same dates, respectively in check plot. Also, the results show that the percent reduction of $M$. persicae in $2^{\text {nd }}$ release plot increased gradually showing 34.29, 52.01, 69.64, 78.09, 79.62, 81.06 and $82.33 \%$ on May, June, July, August, September, October and November, respectively. 


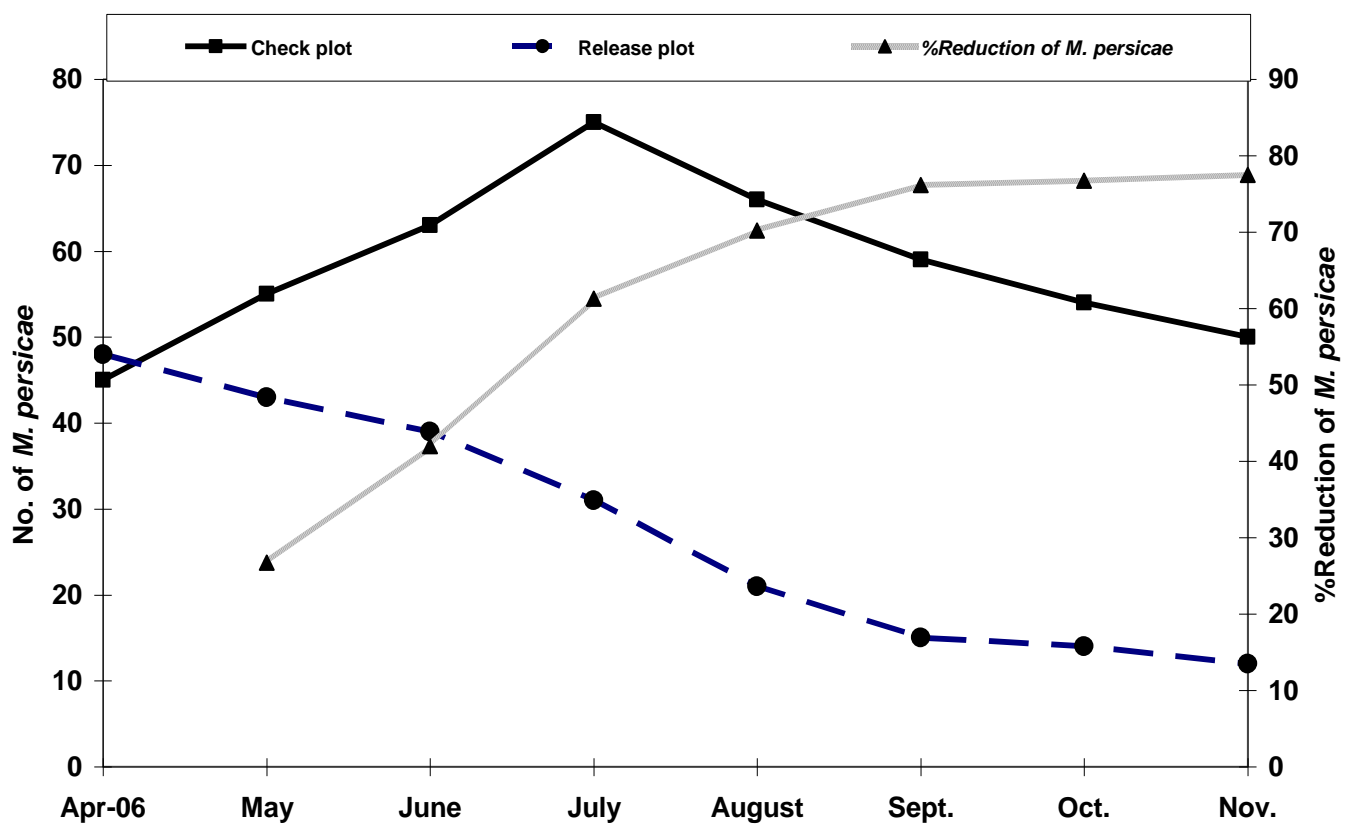

Fig. 1. Population fluctuation of Myzus persicae (Sulz.) in the $1^{\text {st }}$ plot release at level (30 eggs) of Coccinella septempunctata L. and the corresponding \%reduction of the aphid density on peach trees during 2006.



Fig. 2. Population fluctuation of Myzus persicae (Sulz.) in the $2^{\text {nd }}$ plot release at level (60 eggs) of Coccinella septempunctata L. and the corresponding \%reduction of the aphid density on peach trees during 2006. 


\subsection{In third level of release ( 90 eggs/tree):}

In the third level of release, the pre releasing number of aphid species complex before release was 78 individuals/leaf, while it was 83 individuals/leaf in (check trees).

The results in Fig. (3) indicated that the number of $M$. persicae in the $3^{\text {rd }}$ release plot decreased drastically from 78 on April to $64,49,33,21,8,4$ and 2 individuals/leaf in May, June, July, August, September, October and November, respectively while aphid numbers changed from 83 individuals/leaf in April to 112, 128, 147, 112, 91,81 and 77 individuals/leaf in the same dates, respectively in check plot. According$l y$, the percent reduction of aphid population in the $3^{\text {rd }}$ release plot increased gradually from $39.93 \%$ in May to 59.76, 76.39, 82.94, 90.64, 94.75 and $97.24 \%$ in May, June, July, August, September, October and November, respectively.

\section{Second year (2007):}

The three previous maintained levels of release were repeated in the following year (2007).

\subsection{Fist level of release ( 30 eggs/tree):}

In first level of release, the pre-count of aphids was 51 individuals/leaf in the releasing area, while it was also 56 individuals/leaf in (check trees).

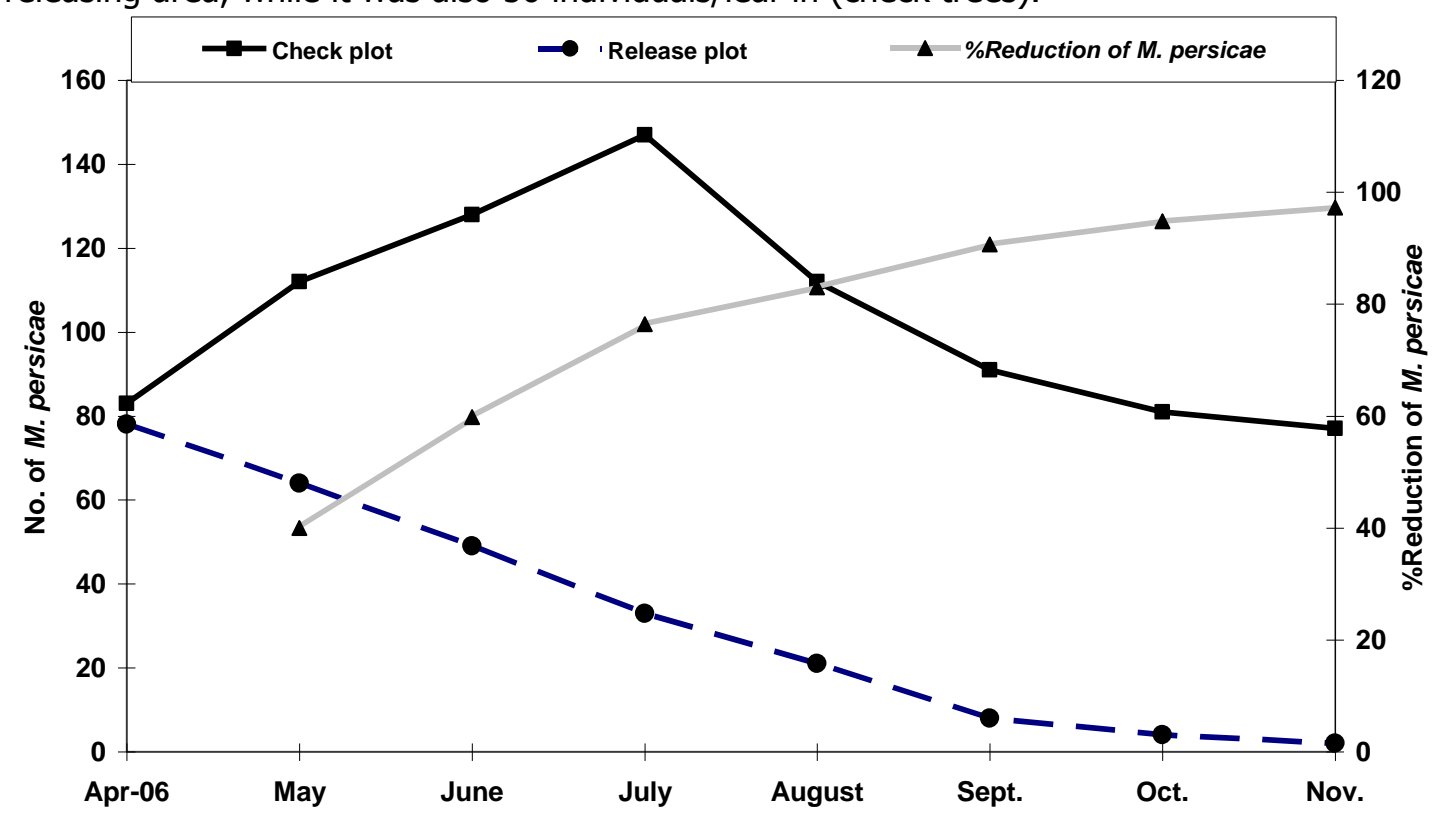

Fig. 3. Population fluctuation of Myzus persicae (Sulz.) in the $3^{\text {rd }}$ plot release at level (90 eggs) of Coccinella septempunctata L. and the corresponding \%reduction of the aphid density on peach trees during 2006. 


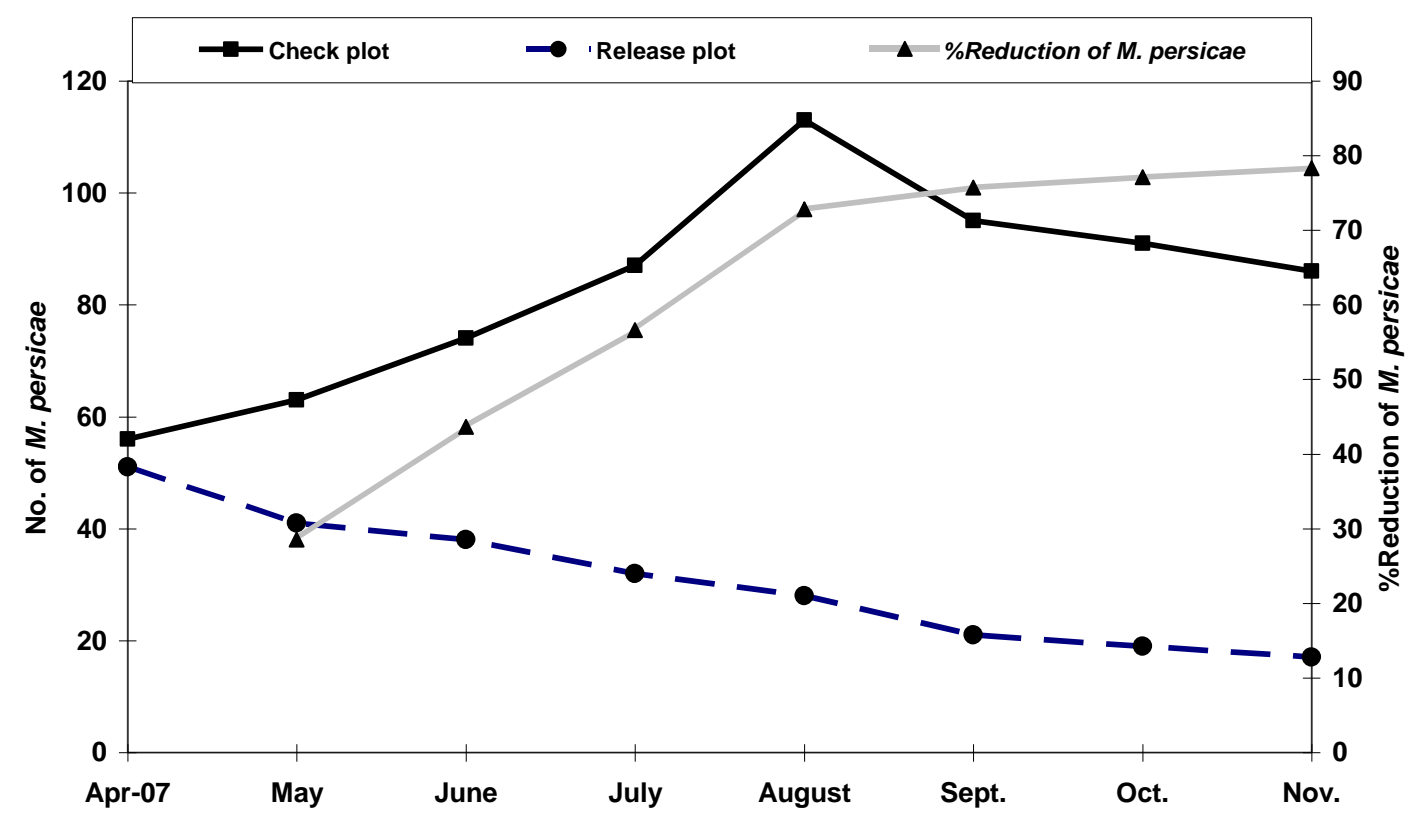

Fig. 4. Population fluctuation of Myzus persicae (Sulz.) in the $1^{\text {st }}$ plot release at level (30 eggs) of Coccinella septempunctata L. and the corresponding \%reduction of the aphid density on peach trees during 2007.

Data shown in Fig. (4) clear that the number of M. persicae in the $1^{\text {st }}$ release plot decreased gradually from 51 in April to 41, 38, 32, 28, 21, 19 and 17 in May, June, July, August, September, October and November, respectively. However, their numbers were $56,63,74,87,113,95,91$ and 17 individuals/leaf in the same dates, respectively in check plot. Also, the results show that the percent reduction in aphid population increased gradually to reach 28.54, 43.61, 59.61, 72.79, 75.73, 77.07 and $78.29 \%$ on May, June, July, August, September, October and November, respectively in this level of release (Fig. 4).

\subsection{Second level of release ( 60 eggs/tree):}

In the second level of release, the pre-count number of aphid species complex in release area was 82 individuals/leaf, while it was 87 individuals/leaf in (check trees).

The results in Fig. (5) indicated that the number of aphid population in the $2^{\text {nd }}$ release plot decreased gradually from 82 in April to 62, 55, 49, 24, 18, 15 and 12 individuals/leaf on May, June, July, August, September, October and November, respectively, while it declined 87 individuals/leaf in April to 98, 119, 132, 102, 89, 81 and 77 individuals/leaf an the same dates, respectively in check plot. Also, the results show that the percent reduction in aphid population in $2^{\text {nd }}$ release plot increased gradually 
showing $32.87,50.96,60.62,75.06,78.54,80.35$ and $83.47 \%$ on May, June, July, August, September, October and November, respectively.

\subsection{In third level of release ( 90 eggs/tree):}

In the third level of release the pre-releasing number of aphid before release was 71 individuals/leaf, while it was 75 individuals/leaf in check trees.

The results in Fig. (6) indicated that the number of aphid in the $3^{\text {rd }}$ release plot decreased drastically from 71 in April to 54, 50, 45, 18, 11, 9 and 4 individuals/leaf in May, June, July, August, September, October and November, respectively while, its predator changed from 75 individuals/leaf in April to $91,125,133,98,81$, 72 and 53 individuals/leaf in the same dates, respectively). Also, the results show that the percent reduction in aphid population in $3^{\text {rd }}$ release plot increased gradually reaching 37.32, 57.75, 64.26, 80.59, 85.85, 86.80 and 92.03\% during May, June, July, August, September, October and November, respectively in this level of release.

Obtained results are in agreement with those recorded by Mangoud, 2007 (in press) who stated Coccinella septempunctata $\mathrm{L}$. is an important predator of aphids, it plays a good role in reducing the population density of the woolly apple aphid, Eriosoma lanigerum (Hausmann) (Homoptera : Aphididae) attacking apple trees.

The results which obtained during the first year (2006) showed that as a result of releasing $C$. septempunctata, the numbers of $M$. persicae which infesting the terminal shoots (new leaves) decreased, also the predator could be established in this farm, therefore the infestation by M. persicae in the second year (2007) also sensationally reduced.

These results are in harmony with those obtained by Hoyt and Madsen (1960) who found that the control of aphid species complex is complicated by the continual dispersal of aphids from the roots to the aerial portions of the tree, and a corresponding dispersal in the opposite direction. Release $C$. septempunctata adopted here can cope very well with this behaviour. 


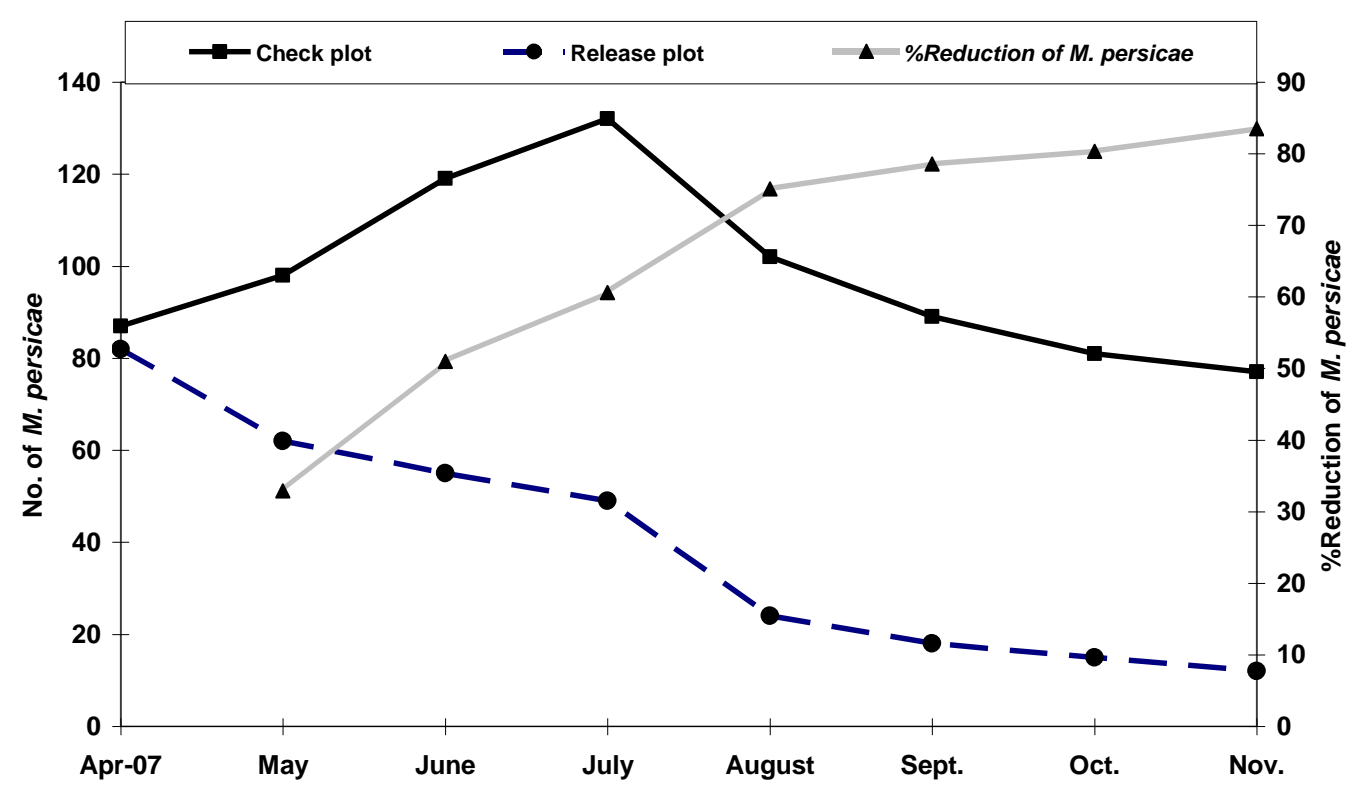

Fig. 5. Population fluctuation of Myzus persicae (Sulz.) in the $2^{\text {nd }}$ plot release at level (60 eggs) of Coccinella septempunctata L. and the corresponding

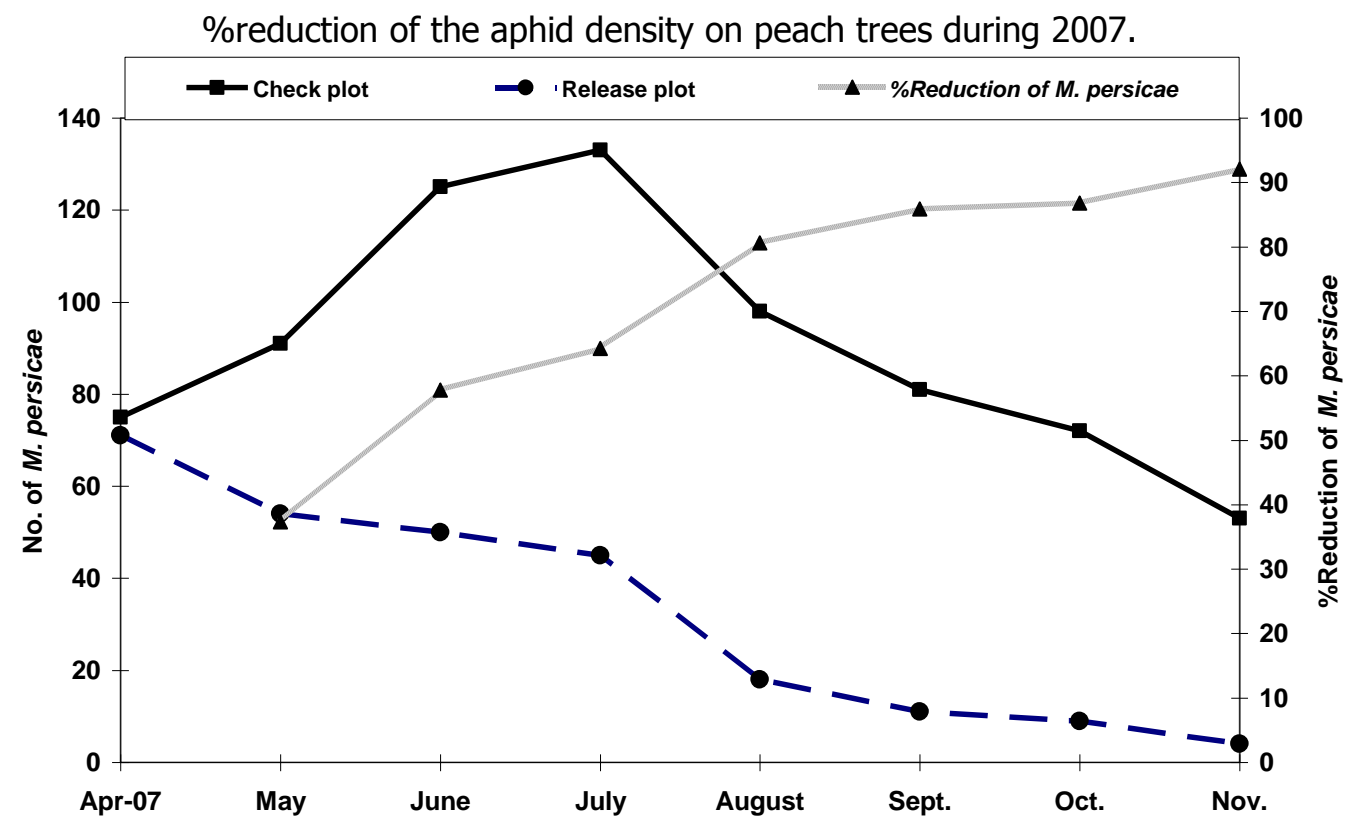

Fig. 6. Population fluctuation of Myzus persicae (Sulz.) in the $3^{\text {rd }}$ plot release at level (90 eggs) of Coccinella septempunctata L. and the corresponding \%reduction of the aphid density on peach trees during 2007. 


\section{REFERENCES}

1. Anonymous. 1997. Ladybird Beetle. Microsoft Encarta 97 Encyclopedia. Houghton Mifflin Company.

2. Arnett J.; N. M. Ross; and H. E. Jaques. 1980. How To Know The Beetles. W. C. Brown Company Publishers, Dubuque, Iowa.

3. Fleming, R. C. 2000. Entomology Notes 6: Lady Beetles. http://insects.ummz.Isa.umich.edu/MES/notes/entnotes6.html.

4. Hendrson, C.F. and E.W. Tilton. 1955. Test with acaricides against the brown wheat mite. J. Econ Entomol., 48: 157-161.

5. Hoyt, S. C. and H.F. Madsen. 1960. Dispersal behavior of the first instar nymphs of the woolly apple aphid. Hilgardia, 30:267-297.

6. Ibrahim, M.M. 1948. The morphology and anatomy of Coccinella undecimpunctata aegyptiaca Reiche. Bull. Soc. 1er Entom., XXXII: 305-316

7. Ibrahim, M.M. 1955a. Studies on Coccinella undecimpunctata aegyptiaca Reiche. I. Preliminary notes and morphology of the early stages. Bull. Soc. Entom., Egypt, XXXIX, : 251-274.

8. Ibrahim, M.M. 1955b. Studies on Coccinella undecimpunctata aegyptiaca Reiche. II. Biology and life-history. Bull. Soc. Entom., Egypt, XXXIX, : 395423.

9. Mangoud, A. A. H. 1994. Toxicological studies on some sucking insects infesting apple trees. Unpublished M. Sc. Thesis, Cairo Univ. Cairo, Egypt, 178 pp.

10. Mangoud, A. A. H. 2000. Integrated pest management of apple trees. Ph. D. Thesis, Fac. Agric. Cairo Univ. Cairo, Egypt, 225 pp.

11. Mangoud, A. A. H. 2003. Research worker working on mass rearing of predators during working in the Project 604 "Mass rearing of parasites and predators attacking mealybugs and whiteflies".

12. Mangoud, A. A. H. 2007. Manipulation of the seven spotted lady beetle, Coccinella septempunctata (Coleoptera : Coccinellidae) for controlling the woolly apple aphid, Eriosoma lanigerum (Homoptera : Aphididae). (in press).

13. Waldbauer, G. 1998. The Birder's Bug Book. Harvard University Press, Cambridge, Massachusetts. 


\section{مكافحة من الخوخ الاخضر والذى يصيب أثنجار الخوخ وذلك باطلاق أبو العيد ذو السبع نقاط علي أثجار الخوخ}

\section{أشرف عبد السلام هندي منجود}

$$
\text { معهُ بحوث وقاية النباتات - مركز البحوث الزراعية - الدقي - جيزة - مصر }
$$

يعتبر من الخوخ الأخضر من أهم الآفات التي تصبب أثنار الخوخ في مصر • برتبط بهذا النوع





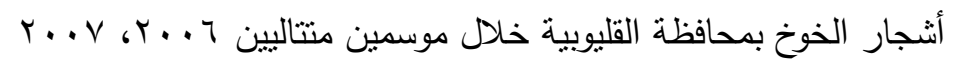
أدي إطلاق هذا المفترس بمستوي • ب بيضة/شجرة الي خفض نسبة الإصابة بالمن بنسبة وصلت



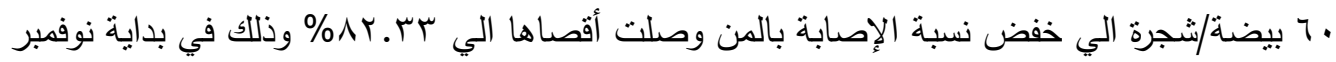



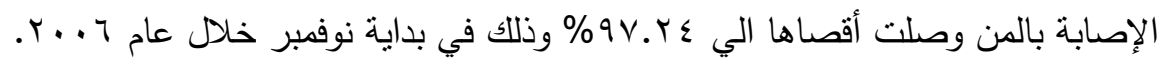



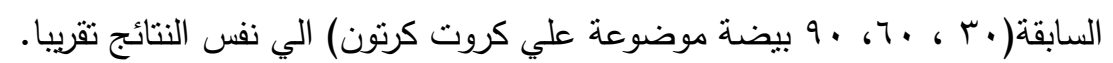



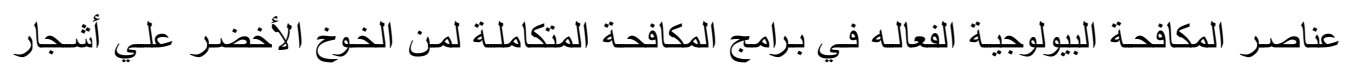

